九州大学学術情報リポジトリ

Kyushu University Institutional Repository

\title{
Insect Cell Extract Preparation by the Nitrogen Disruption Method for Cell-Free Translation
}

\section{Tarui, Hiroshi}

Laboratory of Microbial Genetics Technology, Graduate School of Genetic Resources Technology, Kyushu University

\section{Murata, Masahiro}

Laboratory of Microbial Genetics, Division of Applied Genetic Resources, Department of Genetic Resources Technology, Graduate School of Bioresource and Bioenvironmental Sciences, Kyushu University

\section{Tani, Ikuko}

Laboratory of Microbial Genetics Technology, Graduate School of Bioresource and

Bioenvironmental Sciences, Kyushu University

Imanishi, Shigeo

National Institute of Sericultural and Entomological Science

他

https://doi.org/10.5109/24364

出版情報：九州大学大学院農学研究院紀要. 45（1)，pp.135-148，2000-11. Kyushu University バージョン：

権利関係 : 


\title{
Insect Cell Extract Preparation by the Nitrogen Disruption Method for Cell-Free Translation
}

\author{
Hiroshi Tarui', Masahiro Murata ${ }^{2}$, Ikuko Tani' ${ }^{3}$, Shigeo Imanishi ${ }^{4}$, \\ Shigemichi Nishikawa ${ }^{5}$, and Toshio Hara
}

\begin{abstract}
Laboratory of Microbial Genetics, Division of Applied Genetic Resources, Department of Genetic Resources Technology, Faculty of Agriculture, Kyushu University, Fukuoka 812-8581, Japan

(Received May 23, 2000 and accepted August 18, 2000)
\end{abstract}

\begin{abstract}
An insect cell extract for cell-free translation was prepared using a Mini-Bomb cell disruption chamber, a unique device which disrupts biological materials by altering the pressure on these materials. The highest potential extract for cell-free translation was prepared from the cell suspension at a density of $1.0 \times 10^{8} \mathrm{cells} / \mathrm{ml}$, then disrupted at a nitrogen pressure of $10 \mathrm{~kg} / \mathrm{cm}^{2}$. Furthermore, synthesized proteins were stable in this extract, but were degraded by proteinase in an extract prepared with a Potter-Elvehjem homogenizer. The insect cell extract showed efficient activity for translation of protein $2 \mathrm{a}$ and coat protein of the brome mosaic virus, while inefficiently translating protein la and protein $3 \mathrm{a}$. On the other hand, mainly protein $3 \mathrm{a}$ and coat protein were translated in a wheat germ system, while mainly proteins $2 \mathrm{a}$ and $3 \mathrm{a}$ were translated in a rabbit reticulocyte system. The insect cell-free system appears to possess an unusual property for enhancing translation of exogenous mRNA, making it different from the rabbit reticulocyte and wheat germ systems.
\end{abstract}

\section{INTRODUCTION}

Several types of cell-free translation systems, e. g., wheat germ (Erickson and Blobel, 1983), rabbit reticulocytes (Jackson and Hunt, 1983), Escherichia coli (Chen and Zubay, 1983), yeast (Hussain and Leibowitz, 1986), CHO (Moldave and Fischer, 1983), Ehrlich ascites tumor cells (Henshaw and Panniers, 1983) and many other sources, have been developed. Among these, the traditional systems, i. e., wheat germ extract, rabbit reticulocyte lysate and $E$. coli extract systems, are widely used for synthesizing endogenous and artificial proteins for characterization of the protein or in order to elucidate the translational mechanisms. The productivities of these traditional systems have steadily increased (Madin et al., 2000; Kawarasaki et al., 1995; Nakano et al., 1994; Kim et al., 1996), though it is still difficult to compare in vivo with in vitro phenomena

\footnotetext{
'Laboratory of Microbial Genetics Technology, Graduate School of Genetic Resources Technology, Kyushu University, Fukuoka 812-8581, Japan

${ }^{2}$ Laboratory of Microbial Genetics, Division of Applied Genetic Resources, Department of Genetic Resources Technology, Graduate School of Bioresource and Bioenvironmental Sciences, Kyushu University, Fukuoka 812-8581, Japan

${ }^{3}$ Laboratory of Microbial Genetics Technology, Graduate School of Bioresource and Bioenvironmental

Sciences, Kyushu University, Fukuoka 812-8581, Japan

${ }^{4}$ National Institute of Sericultural and Entomological Science, Tukuba, Ibaragi 305-0851, Japan

${ }^{5}$ Wakenyaku Co. Ltd. Ichijiyoji, Sakyo-ku, Kyoto 606-8175, Japan
} 
using the same sources. Cell-free protein synthesis systems from cultured cells have been developed. However, the major disadvantage of these eukaryote cell-free systems is comparatively low protein productivity. With attempts to increase the productivity of existing systems, the development of a new system derived from another source has been anticipated.

The insect cell-baculovirus expression system has been used for high level expression of a wide variety of recombinant proteins. Insect cells infected with a recombinant baculovirus have the potential to produce large amounts of foreign proteins when gene expression is regulated by the very late polyhedrin and p10 promoters (Hara et al., 1993; Lukow and Summers, 1988; Vlak et al., 1988). Many mammalian proteins which require posttranslational modifications have been successfully expressed in recombinant baculovirus infected insect cells (Lukow and Summers, 1988). These posttranslational modifications which include glycosylation, cis-trans isomerasation of prolyl residues and disulfide bond formation occur, or are facilitated, within the secretory pathway of eukaryotic cells. Therefore, recombinant proteins that have to undergo these modifications must be targeted to the cellular secretory pathway. A cell-free translation system derived from insect cells described by Scheper et al. (1997) had the properties of the untranslated region (UTR) of the baculovirus p10mRNA. This system was prepared using a method of Drosophila cell-free system and the productivity and the characteristics of the system were not described.

In order to prepare a highly efficient cell-free protein synthesis system, it is of the utmost importance to extract components that participate in protein synthesis with high efficiency. Furthermore, traditional cell-free protein synthesis systems such as the wheat germ and rabbit reticulocyte cell-free systems cannot synthesize glycosylated protein. To produce glycosylated protein, the addition of canine pancreatic microsomes to the traditional cell-free protein synthesis system is necessary (Walter and Blobel, 1983). Wheat germ is disrupted by grinding and reticulocytes burst in water, such that the microsome in the wheat germ extract and reticulocyte lysate may also be disrupted or burst. Likewise, most extracts derived from cultured cells are swelled in hypotonic buffer and disrupted with the use of a tight-fitting Dounce homogenizer (Moldave and Fischer, 1983; Henshaw and Panniers, 1983), in which microsomes may also swell and undergo homogenization. The osmotic shock can lead to inefficient translation and failure of posttranslation.

The Mini-Bomb cell disruption chamber (Mini-Bomb) is a unique device designed to disrupt many biological materials while allowing high activity to be preserved. In the Mini-Bomb, compressed gas from a standard high-pressure tank is applied to the biological material at the desired pressure. Following equilibration, the sample is released through a needle valve. The sudden decompression causes controlled disruption of the biological material. In a recent study (Tarui, Imanishi and Hara, unpublished results), we introduced this device to achieve disruption of insect cells in order to prepare an extract for cell-free protein synthesis. We found the insect cell-free system obtained to be capable of translating exogenous mRNA efficiently and of glycosylating the nascent polypeptide in intact microsomes. However, the optimal conditions for cell disruption with the Mini-Bomb were not established. Moreover, the insect cell-free system was not fully characterized. 
In this experiment, the optimal conditions for cell disruption with the Mini-Bomb, aimed at preparation of an insect cell extract retaining translation activity, were determined. In addition, we also found that the insect cell-free system had translatability different from that of the wheat germ extract and reticulocyte lysate systems.

\section{MATERIALS AND METHODS}

\section{Cell culture conditions}

The IPLB-Sf21-AE II (Vaughn et al., 1977) was routinely maintained as a spinner culture at $27^{\circ} \mathrm{C}$ at densities between 0.1 and $1.5 \times 10^{6}$ cells per milliliter in IPL-41 medium (Gibco BRL Life Sciences) supplemented with $10 \%$ (v/v) heat-inactivated fetal bovine serum (Gibco BRL Life Sciences).

\section{Preparation of insect cell extract}

Cells were harvested at a density of $1.0 \times 10^{6}$ cells $/ \mathrm{ml}\left(4.0 \times 10^{8}\right.$ cells total $)$, then washed three times with extraction buffer $\left(40 \mathrm{mM}\right.$ Hepes- $\mathrm{KOH} \mathrm{pH} 7.95$ at $25^{\circ} \mathrm{C}, 100 \mathrm{mM}$ $\left.\mathrm{KOAc}, 1 \mathrm{mM} \mathrm{Mg}(\mathrm{OAc})_{2}, 2 \mathrm{mM} \mathrm{CaCl}, 4 \mathrm{mM} \mathrm{DTT}\right)$. The cell pellet was resuspended in a half volume of extraction buffer (approximately $1.0 \times 10^{8}$ cells $/ \mathrm{ml}$ ). The cells in the extraction buffer were transferred to the cold Mini-Bomb cell disruption chamber (KONTES Glass Company, Vineland, NJ). The cell suspension was pressurized and allowed to equilibrate for $30 \mathrm{~min}$ at nitrogen pressure of $10 \mathrm{~kg} / \mathrm{cm}^{2}$. The cells were then disrupted to flow under atmospheric pressure at the flow rate of $4 \mathrm{ml} / \mathrm{min}$. This preparation ("pressate") was kept on ice. The efficiency of cell lysis was checked by counting the cells in a lysate diluted with extraction buffer and stained with trypan blue in a hemocytometer under a microscope. For the Potter--Elvehjem homogenizer, a cell suspension at a density of $1.0 \times 10^{8}$ cells $/ \mathrm{ml}$ was homogenized with 5 strokes of the motor-driven Potter-Elvehjem homogenizer at $500 \mathrm{rpm}$. The disrupted cells were centrifuged for $15 \mathrm{~min}$ at $14000 \mathrm{rpm}$ at $4^{\circ} \mathrm{C}$ in a SW40Ti rotor. The pellet was discarded and the supernatant (approximately $2 \mathrm{ml}$ ) was collected and chromatographed through a Sephadex G-25 fine column $(16.0 \times 1.0 \mathrm{~cm})$, previously equilibrated with column buffer (40 mM Hepes-KOH pH 7.95 at $25^{\circ} \mathrm{C}, 100 \mathrm{mM} \mathrm{KOAc}, 5 \mathrm{mM} \mathrm{Mg}(\mathrm{OAc})_{2}, 4 \mathrm{mM}$ DTT). Fractions of $0.5 \mathrm{ml}$ were eluted with the same buffer. The two fractions with the highest $\mathrm{RNA} /$ protein concentration were pooled and aliquoted, immediately frozen in liquid nitrogen, and stored at $-80^{\circ} \mathrm{C}$.

Prior to using the extract for cell-free protein synthesis, endogenous mRNA was digested with micrococcal nuclease (Pelham and Jackson, 1976) as follows: $1 \mu \mathrm{l}$ of nuclease $(1000 \mathrm{U} / \mathrm{ml})$ and $2 \mu \mathrm{l}$ of $40 \mathrm{mM} \mathrm{CaCl}_{2}$ were added to $20 \mu \mathrm{l}$ of extract diluted with the same volume of water and incubated for $5 \mathrm{~min}$ at $20^{\circ} \mathrm{C}$. The digestion was stopped by addition of $2 \mu \mathrm{l}$ of $80 \mathrm{mM}$ EGTA. After the digestion reaction, $3.5 \mu \mathrm{l}$ of creatine phosphokinase $(10 \mathrm{mg} / \mathrm{ml}$ dissolved in $10 \mathrm{mM}$ Hepes-KOH $\mathrm{pH} 7.95)$ were added to the nuclease-treated extract.

\section{Cell-free protein synthesis}

The insect cell-free protein synthesis reaction $(5 \mu \mathrm{l})$ contained $3.2 \mu \mathrm{l}$ of insect cell extract, $20 \mu \mathrm{g} / \mathrm{ml}$ of BMV mRNA, $20.6 \mathrm{mM}$ Hepes- $\mathrm{KOH}\left(\mathrm{pH} 7.95\right.$ at $25^{\circ} \mathrm{C}$ ), $1.5 \mathrm{mM}$ 
$\mathrm{Mg}(\mathrm{OAc})_{2}, 100 \mathrm{mM} \mathrm{KOAc}, 2.5 \mathrm{mM} \mathrm{DTT}, 1.2 \mathrm{mM} \mathrm{ATP}, 0.25 \mathrm{mM} \mathrm{GTP}, 444 \mu \mathrm{g} / \mathrm{ml}$ creatine phosphokinase, $8.0 \mathrm{mM}$ creatine phosphate, $0.25 \mathrm{mM}$ spermidine, $0.32 \mu \mathrm{l}$ of biotinylated lysyl-t RNA and $25 \mu \mathrm{M}$ of 19 amino acids (minus lysine). Assays were carried out at $27^{\circ} \mathrm{C}$ for $90 \mathrm{~min}$.

\section{Detection of synthesized protein}

Aliquots from the protein synthesis reactant were dissolved in SDS-sample buffer and boiled for $5 \mathrm{~min}$. The obtained samples were electrophoresed on $10 \%$ polyacrylamide gels together with molecular weight markers (Bio-Rad). Following electrophoresis, biotinylated polypeptides were transferred to PVDF membranes. Non-specific binding sites were blocked by incubation in 5\% skim milk dissolved in PBS for $1 \mathrm{~h}$ at room temperature. After washing the PVDF membranes three times with PBS containing 1\% Tween-20, the membranes were incubated with 1/1000 diluted streptavidin conjugated horseradish peroxidase (HRP) (Amersham Pharmacia Biotech) for $1 \mathrm{~h}$. Following washing as described above, the transferred proteins were incubated with ECL reagents (Amersham Pharmacia Biotech) for $1 \mathrm{~min}$ according to the supplier's instructions. The biotinylated bands were visualized by exposure to an X-ray film (Fuji photo film). Quantitation of products was carried out using the computing densitometer Image Quant (Molecular Dynamics).

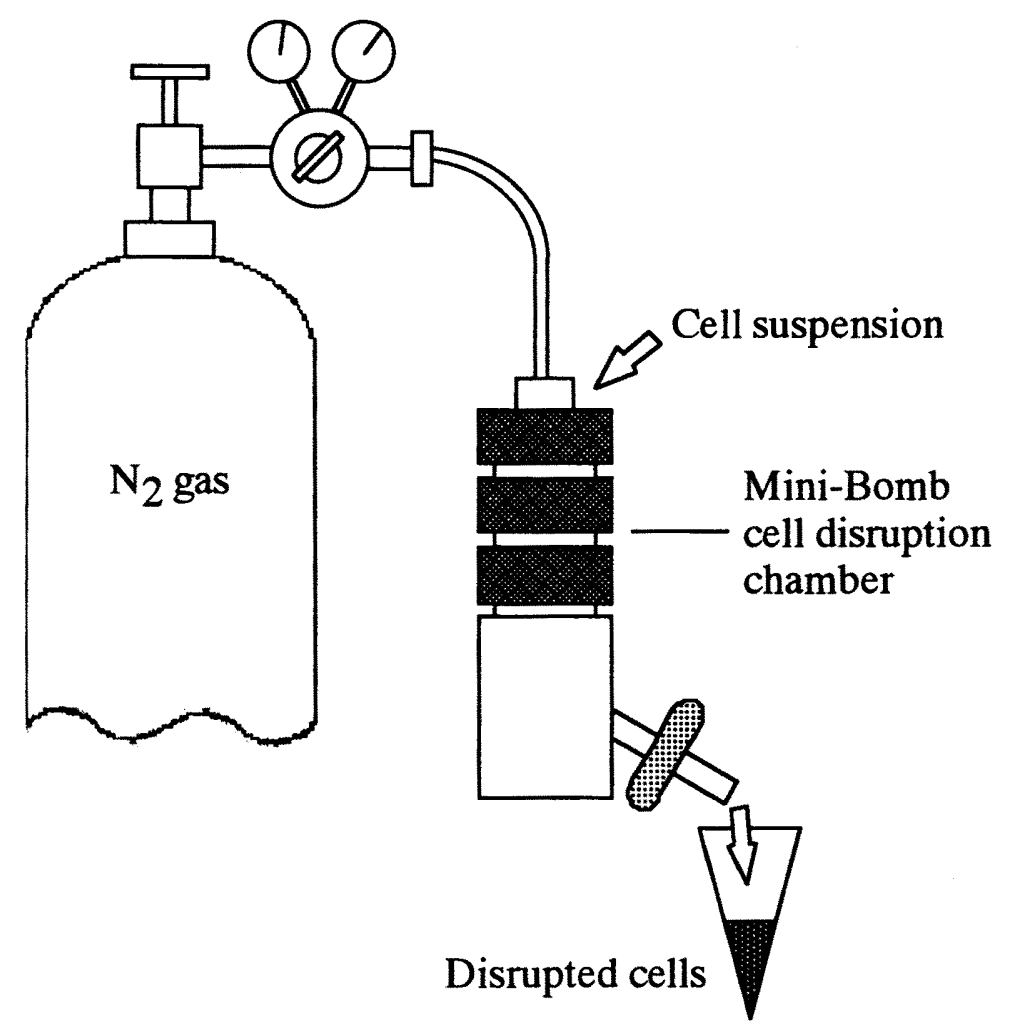

Fig. 1. Mini-Bomb cell disruption chamber. 


\section{RESULTS}

\section{Disruption efficiency with Mini-Bomb cell disruption chamber}

With the aim of extracting intact translation machinery, the Mini-Bomb was used to break the cell membrane. The Mini-Bomb is a device designed to disrupt biological materials with nitrogen pressure. Figure 1 illustrates the Mini-Bomb. The cell suspension of biological materials in the Mini-Bomb was placed under pressure, from nitrogen gas derived by a pressure tank, and equilibrated for an adequate time. The needle valve was opened gently and slowly such that the entire suspension was extruded through the orifice. Alteration of nitrogen pressure and flow rate resulted in controlled disruption. Furthermore, nitrogen gas prevents the biological materials from oxidating.

The pressure placed on the cell suspension might be the most remarkable factor contributing to the disruption of cells while allowing translational efficiency to be

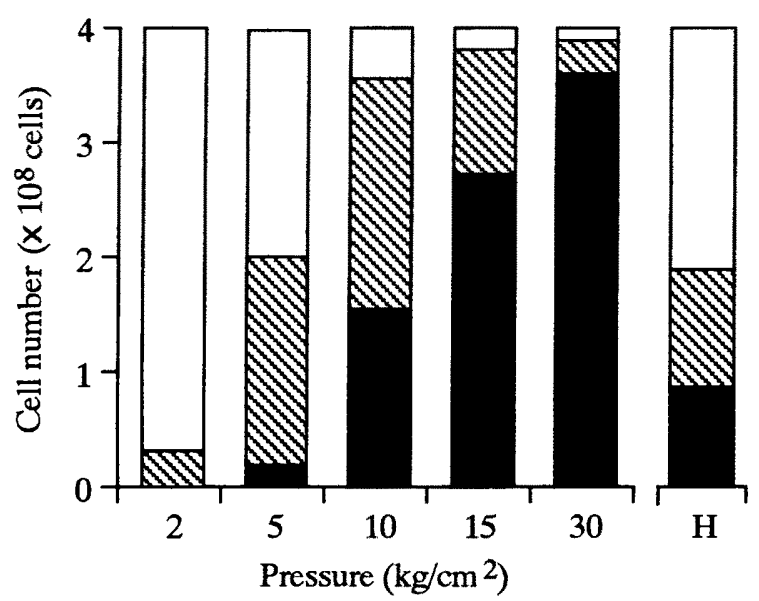

Fig. 2. Disruption efficiency of $\mathrm{Sf} 21$ cells using the Mini-Bomb cell disruption chamber and the Potter-Elvehjem homogenizer.

Sf21 cell $\left(4.0 \times 10^{8}\right.$ cells $)$ suspensions in $4 \mathrm{ml}$ of extraction buffer were placed in a cold Mini-Bomb and then equilibrated for $30 \mathrm{~min}$ under nitrogen gas pressure, as indicated. The suspensions were then released from the Mini-Bomb at a flow rate of approximately $4 \mathrm{ml} / \mathrm{min}$. The suspended cells were also disrupted by 5 strokes at $500 \mathrm{rpm}$ with a motor-driven Potter-Elvehjem homogenizer. The disrupted cells were stained with trypan blue to visualize the nuclei and counted in a hemocytometer under a microscope. Incomplete disruption was indicated by persisting nuclei. The number of cells disrupted completely or incompletely was indicated as solid bars or hatched bars, respectively. Open bars indicated undisrupted cells. The disruption efficiency achieved with the Potter-Elvehjem homogenizer is indicated by column $\mathrm{H}$. 
retained. Figure 2 shows the effect of nitrogen pressure on the degree of cell membrane disruption. When a nitrogen pressure of $5 \mathrm{~kg} / \mathrm{cm}^{2}$ was applied, the membranes of half of all cells placed in the Mini-Bomb were ruptured, though nearly $40 \%$ of the nuclei remained intact. More than $80 \%$ of cells placed in the Mini-Bomb were disrupted at a nitrogen pressure of $15 \mathrm{~kg} / \mathrm{cm}^{2}$ or higher. Even though the higher-pressure treatment resulted in more efficient disruption, nuclei and other organelles were more likely to be damaged, resulting in contamination of the pressate with these components. In contrast, lower pressure $\left(2 \mathrm{~kg} / \mathrm{cm}^{2}\right)$ treatment caused inefficient disruption. Only about $30 \%$ of all cells were disrupted when the motor-driven Potter-Elvehjem homogenizer was used. Furthermore, half of the cells placed in the Potter-Elvehjem homogenizer were disrupted incompletely and cytosol of the cells remained with partially damaged cell membranes.

A

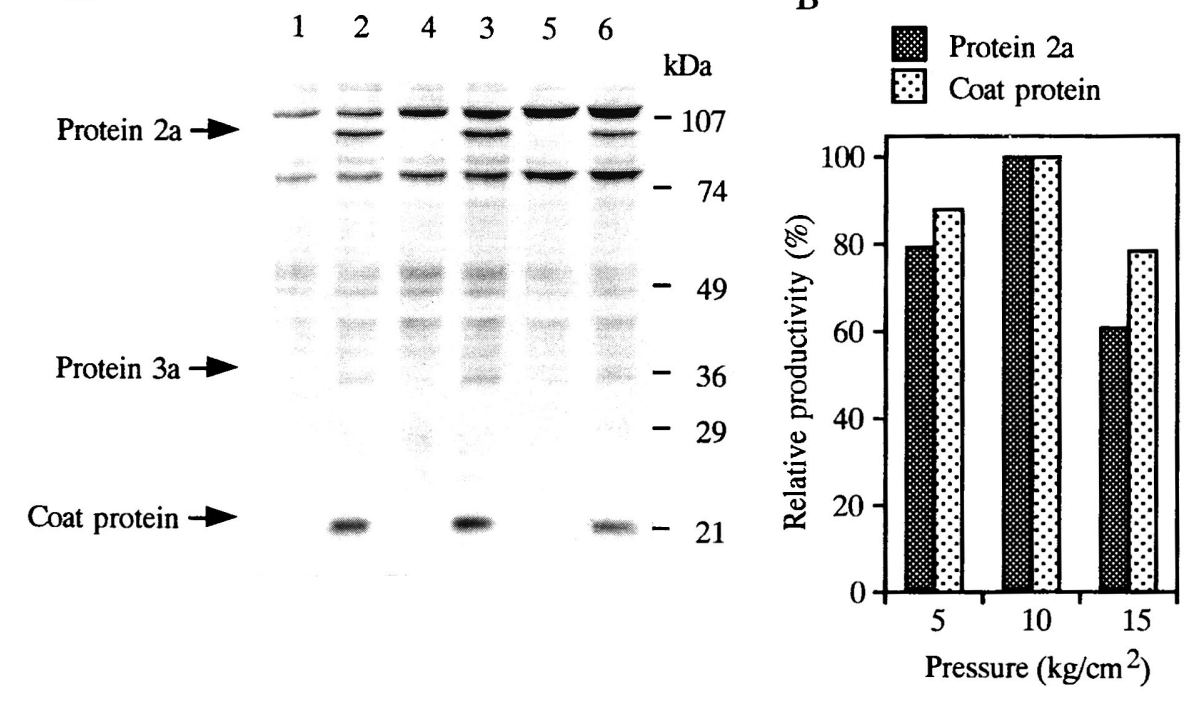

Fig. 3. Effect of nitrogen gas pressure on protein productivity of the insect cell extract.

(A) Following preparation of the insect cell extracts from $4.0 \times 10^{8}$ cells disrupted using the Mini-Bomb cell disruption chamber at nitrogen pressures of 5 (lanes 1, 2), 10 (lanes 3,4 ) and 15 (lanes 5,6 ) $\mathrm{kg} / \mathrm{cm}^{2}$, translational reactions were carried out with (lanes 2,4 and 6) or without (lanes 1,3 and 5) BMV mRNA in the presence of biotinylated lysyl-tRNA, as described in Materials and Methods. Biotinylated polypeptides were separated on a $12.5 \%$ SDS-PAGE gel and transferred to PVDF membranes. The biotinylated bands were visualized using HRP-streptavidin and an ECL kit. (B) Relative productivity was densitometorically estimated by calculating the amounts of protein $2 \mathrm{a}$ and coat protein synthesized. The amounts of protein $2 \mathrm{a}$ and coat protein synthesized, in the extract prepared with a nitrogen pressure of $10 \mathrm{~kg} / \mathrm{cm}^{2}$, were each set at $100 \%$. 


\section{Cell-free translation of BMV mRNA}

The insect cell extract preparation and the conditions of cell-free translation were based on a method described by Erickson and Blobel (1983) for preparation of wheat germ extract, with minor modifications. Cell-free translation in an insect cell extract was carried out with addition of brome mosaic virus (BMV) mRNA as an exogenous mRNA. The BMV has three genomic RNAs (RNAs 1-3) and one subgenomic RNA4 (Shin et al., 1972; 1976; Bastin et al., 1976). RNA1-3 and subgenomic RNA4 code proteins 1a, 2a, and $3 \mathrm{a}$ and coat protein, respectively. When the BMV mRNAs were translated in the insect cell-free system, mainly two types of protein, i. e., protein $2 \mathrm{a}$ and coat protein, were synthesized (Fig. 3A). Hence, in this experiment, the protein productivity of the insect cell-free system was monitored according to the amounts of protein $2 \mathrm{a}$ and coat protein synthesized.

\section{Optimal disruption conditions with the Mini-Bomb cell disruption chamber}

Optimal disruption conditions for preparing a high productivity extract were systematically determined, in terms of nitrogen pressure, cell density upon placement in the Mini-Bomb, equilibration time and flow rate.

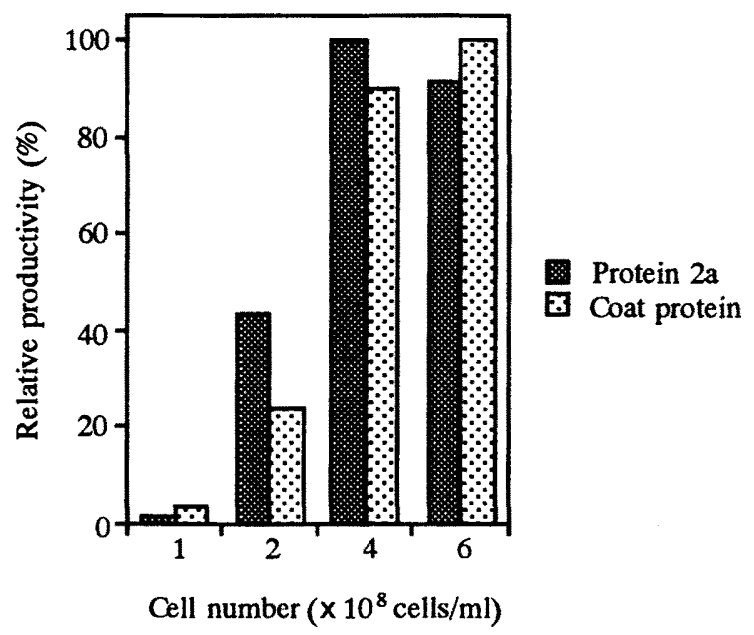

Fig. 4. Effect of cell density on protein productivity of insect cell extract.

Following the placement of the cell suspensions at various densities as indicated into the Mini-Bomb, the suspensions were subjected to $10 \mathrm{~kg} / \mathrm{cm}^{2}$ nitrogen pressure and allowed to equilibrate for $30 \mathrm{~min}$. After disruption, the extracts were prepared from the obtained pressate as described in Materials and Methods. After translation with BMV mRNA in the extracts, biotinylated products were detected using HRP-streptavidin and an ECL kit, as described in Materials and Methods. The product amounts were estimated densitometorically. 
First, the effect of nitrogen pressure on protein productivity was examined (Fig. 3). Harvested cells $\left(4 \times 10^{8}\right.$ cells) were resuspended to $4 \mathrm{ml}$ in extraction buffer and subjected to a pressure of $10 \mathrm{~kg} / \mathrm{cm}^{2}$ for $30 \mathrm{~min}$, after which the cells were disrupted with decompression. The extracts derived from the pressate prepared at a nitrogen pressure of $10 \mathrm{~kg} / \mathrm{cm}^{2}$ had the highest productivity of both protein $2 \mathrm{a}$ and coat protein. Higher-pressure treatment disrupted insect cells efficiently, but reduced the protein productivity of the obtained extract. Higher-pressure treatment appears to be excessive for preparing the extract for cell-free translation, as the translation machinery may also be damaged with higher nitrogen pressure.

Secondly, the influence of suspension at various cell densities applied to the chamber, on the protein productivity of the obtained extract, was examined. Harvested cells were resuspended to $4 \mathrm{ml}$ in extraction buffer at various cell densities and subjected to a pressure of $10 \mathrm{~kg} / \mathrm{cm}^{2}$ for $30 \mathrm{~min}$, after which the cells were disrupted with decompression. Figure 4 shows the protein productivity of the obtained extract. The highest productivity was observed in the extract prepared from cell suspensions of 1.0 and $1.5 \times 10^{8} \mathrm{cells} / \mathrm{ml}$, which represent the suspension in the buffer of half of the packed cell volume and the cell pellet obtained with centrifugation at $600 \times \mathrm{g}$ for $10 \mathrm{~min}$,

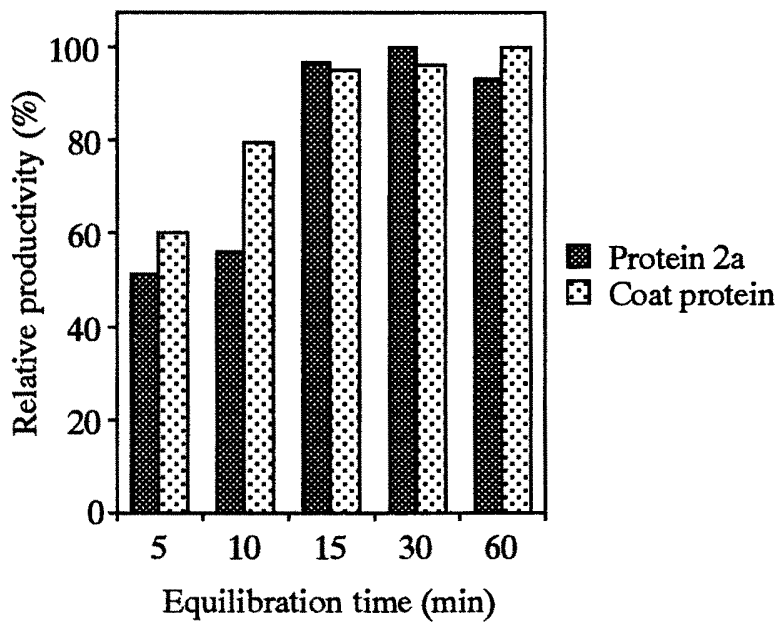

Fig. 5. Effect of equilibration time on protein productivity.

Following the placement of cell suspensions $\left(1.0 \times 10^{8}\right.$ cells $/ \mathrm{ml}$ ) into the Mini-Bomb, the suspensions were subjected to $10 \mathrm{~kg} / \mathrm{cm}^{2}$ nitrogen pressure and allowed to equilibrate for various times. After disruption, the extracts were prepared from the obtained pressate, as described in Materials and Methods. After translation with BMV mRNA in the extracts, biotinylated products were detected using HRP-streptavidin and an ECL kit, as described in Materials and Methods. The product amounts were estimated densitometorically. 
respectively. These results indicate that the Mini-Bomb has the ability to efficiently extract intact translation machinery from cells suspended at a high density.

Next, the effect of equilibration time on the protein productivity of the extract prepared from pressates obtained using various equilibration times was examined. After applying a pressure of $10 \mathrm{~kg} / \mathrm{cm}^{2}$ on suspensions of $1.0 \times 10^{8}$ cells $/ \mathrm{ml}$, the suspensions were equilibrated for desired periods (Fig. 5). We found that the cell suspension needed to equilibrate for at least $15 \mathrm{~min}$ to acquire efficient translation activity. At this time point, the nitrogen gas may prevent the pressate from being oxidized and inactivated.

Finally, the influence of the flow rate at the decompression step on protein productivity was examined. Extracts derived from the pressate extruding through the orifice at flow rates of 12,4 and $1 \mathrm{ml} / \mathrm{min}$ produced essentially the same amounts of protein $2 \mathrm{a}$ and coat protein (data not shown). The flow rate thus had no influence on the protein productivity of the obtained extracts.

\section{Translation efficiency and stability of synthesized proteins}

To clarify the usefulness of the Mini-Bomb for producing the extract for cell-free protein synthesis, the translation efficiency of the insect cell extract was compared with that of the extract prepared with the Potter-Elvehjem homogenizer. The insect cell extract was prepared with the Mini-Bomb or the motor-driven Potter-Elvehjem homogenizer under optimal conditions, determined in accordance with the amount of protein produced in a $90 \mathrm{~min}$ period (for Potter-Elvehjem homogenizer, data not shown). The extracts prepared with the Mini-Bomb and the Potter-Elvehjem homogenizer had
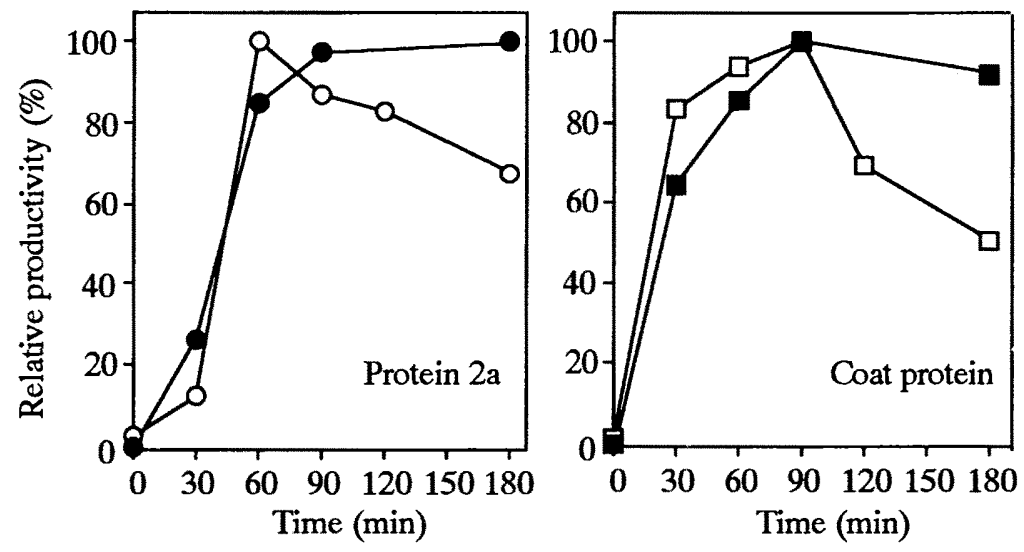

Fig. 6. Time course of protein synthesis in insect cell extracts prepared with the Mini-Bomb and the Potter-Elvehjem homogenizer.

Translation reactions were carried out with BMV mRNA in insect cells prepared with the Mini-Bomb $(\mathbf{O}, \mathbf{D})$ or the Potter-Elvehjem homogenizer $(\bigcirc, \square)$, as described in Materials and Methods. Relative productivity was estimated densitometorically by calculating the amounts of protein $2 \mathrm{a}$ and coat protein synthesized. The amounts of protein $2 \mathrm{a}$ and coat protein synthesized in the each of the extracts were set at $100 \%$. 


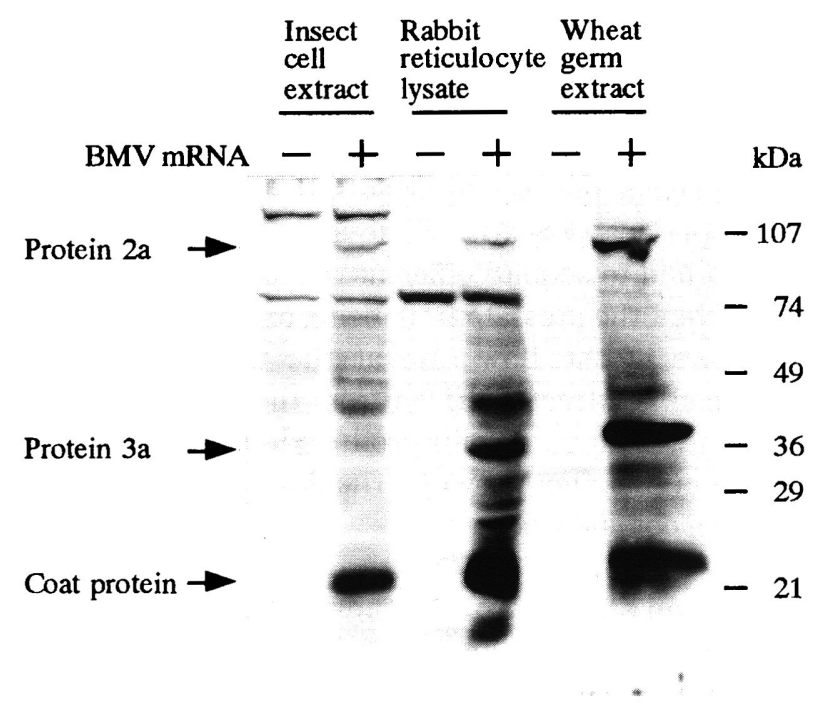

Fig. 7. Comparison of translational profile among various cell-free systems.

Translation of BMV protein with the insect cell-free system was carried out in the presence of biotinylated lysyl-tRNA under the optimal conditions as described in Materials and Methods. Cell-free translations with wheat germ extract and reticulocyte lysate were carried in the presence of biotinylated lysyl-tRNA according to the supplier's instructions. Reaction mixtures of $5 \mathrm{ml}$ were separated on a $12.5 \%$ SDS-PAGE gel and transferred to a PVDF membrane. The biotinylated bands were visualized using HRP-streptavidin and an ECL kit.

similar rates of protein synthesis (Fig. 6). Translations of both protein $2 \mathrm{a}$ and coat protein persisted for about $90 \mathrm{~min}$ in the insect cell extracts prepared with the MiniBomb and the Potter-Elvehjem homogenizer. After termination of the reaction, the synthesized proteins were stable in the reaction mixture of the extract prepared with the Mini-Bomb. In contrast, both protein 2a and coat protein, synthesized in the extract prepared with the Potter-Elvehjem homogenizer, were degraded over time and about $60 \%$ of synthesized coat protein had degraded within $180 \mathrm{~min}$. Potter-Elvehjem homogenizer treatment may disrupt lysosomes and release proteinase, leading to the degradation of synthesized proteins.

\section{Comparison of translational ability among various cell-free systems}

To clarify the specificity of the insect cell-free system, BMV mRNA was translated in the insect, wheat germ and rabbit reticulocyte cell-free systems. When the BMV mRNAs were translated in the insect extract system, mainly two kinds of protein, i. e. protein $2 \mathrm{a}$ and coat protein, were synthesized (Fig. 3, 7). However, protein 1a and protein 3a were not clearly visualized. In contrast, protein $2 \mathrm{a}$ and protein $3 \mathrm{a}$ were mainly detected in the 
reticulocyte lysate system, and protein $3 \mathrm{a}$ and coat protein in the wheat germ extract system. Thus, the translation of BMV mRNAs was controlled in a cell-specific manner. These observations suggest translational regulation of the insect cell translation machinery to be specific to the wheat germ or rabbit reticulocyte systems.

\section{DISCUSSION}

The Mini-Bomb cell disruption chamber is an apparatus designed to achieve disruption of several materials including cells and intracellular components. Gas from a high-pressure tank is introduced into the Mini-Bomb where it is applied to individual cells during the pressure cycle. When the pressurized cell suspension is suddenly exposed to atmospheric pressure, the gas expands and ruptures the cells forming a pressate. Unlike mechanical shearing methods based on the Potter-Elvehjem homogenizer or the Dounce homogenizer which rely on bringing external forces into contact with each individual cell, this nitrogen disruption method uniformly ruptures all cells in a suspension. The cell disruption can be controlled by simply varying the nitrogen pressure. The nitrogen disruption method prevents cytosol proteins from being inactivated by oxidation, which is sometimes sustained by mechanical shearing methods operating in air. Many chambers operate on the same principle and are used for a variety of purposes. For example, the Yeda press is widely used for several biological materials. Under low pressure, it is used to yield a preparation of Class A chloroplasts (Belknap and Togasaki, 1981), intact mitochondria (Belknap and Togasaki, 1981), outer and inner envelope membranes from chloroplasts (Block et al., 1983) and to isolate inside--out, thylakoid membrane vesicles from chloroplasts (Anderson et al., 1980). The Yeda press is also used for complete disruption of the organelle membrane, aimed at isolating biologically active proteins within the organelle membrane (Walker and Harwood, 1985), which are difficult to dislodge from the membrane by osmotic shock. The nitrogen disruption method is suitable for breaking down biological materials such as cell and organelle membranes.

In this experiment, the optimal conditions for cell disruption using the Mini-Bomb were determined based on translational efficiency. The cell disruption efficiency increased with rising nitrogen pressure. The degree of disruption was found to be controlled by varying the nitrogen pressure. Furthermore, compared to the PotterElvehjem homogenizer, the Mini-Bomb was capable of disrupt cells with high efficiency, while allowing the translation efficiency of the cells to be retained. The protein concentration of the extract prepared with the Mini-Bomb, at a nitrogen pressure of $10 \mathrm{~kg} / \mathrm{cm}^{2}$, was approximately 3-fold that of the Potter-Elvehjem homogenizer (data not shown). More severe treatment with the Potter-Elvehjem homogenizer reduced the translational efficiency (data not shown). The Dounce homogenizer, which is generally used to homogenize cultured cells, was unable to homogenize insect cells as it was less efficient than the Potter-Elvehjem homogenizer (data not shown).

A higher protein concentration, in the extract condensed with ultrafiltration membranes, raises the translation efficiency (Nakano et al., 1994; Kim et al., 1996). Although the rate of protein synthesis was increased with condensed extract, microsomes in the insect cell extract are apparently damaged and we speculate that a posttranslation 
factor, serving as a signal recognition particle, might also be eluted through the ultrafiltration membrane during the condensation procedure.

To increase the protein concentration of the extract without condensation, the cell density of the cell suspension needs to be increased. Usually, when extracts for cell-free translation are prepared from various cultured cells, the cell pellets are resuspended in packed cell volumes of hypotonic buffer the same to three times volume, then allowed to swell for efficient homogenization. Conversely, the Mini-Bomb allows disruption of the cells resuspended in half the volume of packed cells or even the cell pellet obtained by centrifugation at $600 \times \mathrm{g}$ for $10 \mathrm{~min}$. In this experiment, the extract derived from cells suspended in extraction buffer, instead of hypotonic buffer, (at a density of $1.0 \times 10^{8}$ cells $/ \mathrm{ml}$ ) had more than double the protein productivity of the extract derived from cells suspended in 2 volumes of extraction buffer (at $0.5 \times 10^{8}$ cells $/ \mathrm{ml}$ ). The ability to disrupt the cell suspension at high density resulted in the insect extract having high protein productivity. These observations showed the Mini-Bomb, which has properties of controlled and efficient disruption, to be a suitable device for preparing the extract for a cell-free protein synthesis system. Furthermore, time course analysis revealed synthesized protein to be stable in the reaction mixture derived from the extract prepared with the Mini-Bomb. In contrast, synthesized proteins in the reaction mixture derived from the extract prepared with the Potter-Elvehjem homogenizer were not stable. This obsevation suggested that the Mini-Bomb may only disrupt the cell membrane, leaving organelles, i. e. lysosome, of the cells with intact. That is in agreement with the finding that the extract prepared with the Mini-Bomb had intact microsomes and had the ability not only to synthesize protein, but also to glycosylate the protein in the microsomal lumen. However, the extract prepared with the Potter-Elvehjem homogenizer failed to synthesize glycosylated protein, producing only the polypeptide backbone (Tarui, Imanishi and Hara, unpublished results).

The insect cell extract, in particular, translated protein $2 \mathrm{a}$ and coat protein (Fig. 3, 6). The 3'-UTRs of the four RNAs of BMV contain 3'-terminal nucleotides forming a tRNA-like structure which stimulates the translation of capped (Daniel and Kobayashi, 1994) or uncapped mRNA (Karpova et al., 1995). However, the region of four RNAs might not affect cell-specific translation because these RNAs have high similarity in this region (Ahlquist et al., 1981). The effect of 5'-UTR of BMV mRNA on translation remains unclear. The intrinsic translational efficiency of the mRNA is dependent on cis-acting elements alone or a cis-acting element with the trans-acting factors. Several cis-acting elements exist on 5'-UTR which enhance or inhibit the translational efficiency of eukaryotic mRNA (Yamaguchi et al., 1982; Imataka et al., 1994; Roberts et al., 1997). For instance, the 5'-UTR of growth related protein p23, which affects cell-specific translation efficiency, inhibits translation efficiency in Ehrlich ascites tumor cells, reticulocyte lysate and Xenopus oocytes, whereas the 5'-UTR does not affect translation efficiency in the wheat germ extract (Böhm et al., 1991). The 5'-UTRs of RNAs that contain cap structures at the terminus of each mRNA show weaker homology, except for RNAs 1 and 2 (Ahlquist et al., 1984). The 5'-UTR of BMV RNAs 1 and 2 share substantial homology, there being only two mismatches between the first $42 \mathrm{bp}$, though the remaining $74 \mathrm{bp}$ 5'-UTR of RNA1 constitute a subset of the $103 \mathrm{bp} \mathrm{5'-UTR} \mathrm{of} \mathrm{RNA2.} \mathrm{Although} \mathrm{some}$ regions of the 5'-UTR of RNA3 bear distinguishable homology to RNA1 and 2, the 
remainder show no such homology. Cell-specific translation of RNA2 and RNA3 observed among these cell-free protein synthesis systems is probably regulated by the cis-acting element on the non-homological region of these 5-UTRs. Conversely, the RNA4 of BMV has the 5'-UTR of a short non-coding region of 9 nucleotides (Ahlquist et al., 1984), which might be too short to construct a secondary structure at this region to act as the cis-acting element. The rate of RNA4 translation might be limited by affinity of the cap binding protein eIF $4 \mathrm{E}$ to 5 ' cap structure.

We found the novel Mini--Bomb device to be useful for cell breakage, aimed at preparing an extract for cell-free protein synthesis. Moreover, insect cell extracts, prepared with this device, had the unique property of allowing proteins synthesis, a property lacking in traditional rabbit reticulocyte lysate and wheat germ extract systems.

Many proteins are routinely synthesized using either a rabbit reticulocyte cell-free system or a wheat germ cell-free system. An alternative system is used in the event of one system not being able to synthesize a particular protein efficiently. This insect cellfree system may serve as a novel assay system because of its unique enhancement of mRNA translation, as compared to the traditional systems.

\section{ACKNOWLEDGMENT}

We are grateful to Dr. Y. Endo of Faculty of Engineering, Ehime University, for preparation of the wheat germ extract.

\section{REFERENCES}

Ahlquist, P., R. Dasgupta and P. Kaesberg 1981 Near identity of 3 ' RNA secondary structure in bromoviruses and cucumber mosaic virus. Cell, 23: 183-189

Ahlquist, P., R. Dasgupta and P. Kaesberg 1984 Nucleotide sequence of the brome mosaic virus genome and its implications for viral replication. J. Mol. Biol., 172: 369-383

Anderson, B., C. Sundby, and P. $-\AA$. Albertsson 1980 A mechanism for the formation of inside-out membrane vesicles. Biochim. Biophys. Acta, 559: $391-402$

Bastin, M., R. Dasgupta, T. C. Hall, and P. Kaesberg 1976 Similarity in structure and function of the 3'-terminal region of the four brome mosaic viral RNAs. J. Mol. Biol., 103: 737-745

Belknap, W. R. and R. K. Togasaki 1981 Chlamydomonas reinhardtii cell preparation with altered permeability toward substrates of organellar reactions. Proc. Natl. Acad. Sci. USA, 78: 2310-2314

Block, M. A, A. -J. Dorne, J. Joyard and R. Douce 1983 Preparation and characterization of membrane fractions enriched in outer and inner envelope membranes from spinach chloroplasts. J. Biol. Chem., 258: $13273-13280$

Böhm, H., B. Gross, M. Gaestel, U. -A. Bommer and H. Bielka 1991 The 5-untranslated region of p23 mRNA from the Ehrlich ascites tumor is involved in translation control of the growth related protein p23. Biomed. Biochim. Acta, 50: 1193-1203

Chen, H. -Z. and G. Zubay 1983 Prokaryotic coupled transcription-translation. Methods Enzymol., 101: $674-689$

Daniel, R. G. and M. Kobayashi 1994 The role of the 3'-untranslated region of non-polyadenylated plant viral mRNAs in regulating translational efficiency. Gene, 142: 159-165

Erickson, A. H. and G. Blobel 1983 Cell-free translation of messenger RNA in a wheat germ system. Methods Enzymol., 96: 38-50

Hara, T., K. Nonaka, H. Kawaguchi, S. Ogata and N. Etou 1993 Effects of temperature on Escherichia coli $\beta$-galactosidase expression in baculovirus-insect cell system. Biosci. Biotechnol. Biochem., 57: 996-997

Henshaw, E. C. and R. Panniers 1983 Translational systems prepared from the Ehrlich Ascites Tumor 
Cell. Methods Enzymol., 101: 616-629

Hussain, I. and M. J. Leibowitz 1986 Translation of homologous and heterologous messenger RNAs in a yeast cell-free system. Gene, 46: 13-23

Imataka, H., K. Nakayama, K. Yasumoto, A. Mizuno, Y. Fujii-Kuriyama and M. Hayami 1994 Cell-specific translational control of transcription factor BTEB expression. J. Biol. Chem., 269: 20668-20673

Jackson, R. J. and T. Hunt 1983 Preparation and use of nuclease-treated rabbit reticulocyte lysates for the translation of eukaryotic messenger RNA. Methods Enzymol., 96: 50-74

Karpova, O. V., V. A. Mavrodieva, O. L. Tomashevskaya, N. P. Rodionova and J. G. Atabekov 1995 The 3-untranslated region of brome mosaic virus RNA does not enhance translation of capped mRNAs in vitro. FEBS Lett., 360: 281-285

Kawarasaki, Y., T. Kawai, H. Nakano and T. Yamane 1995 A long-lived batch reaction system of cell-free protein synthesis. Anal. Biochem., 226: $320-324$

Kim, D. -M., T. Kigawa, C. -Y. Choi and S. Yokoyama 1996 A highly efficient cell-free protein synthesis system from Escherichia coli. Eur. J. Biochem., 239: 881-886

Lukow, V. A. and M. D. Summers 1988 Trends in the development of baculovirus expression vectors. Bio/Technology, 6: 47-55

Madin, K., T. Sawasaki, T. Ogasawara and Y. Endo 2000 A highly efficient and robust cell-free protein synthesis system prepared from wheat embryos: Plants apparently contain a suicide system directed at ribosomes. Proc. Natl. Acad. Sci. USA, 97: 559-564

Moldave, K. and I. Fischer 1983 Preparation of cell-free system from chinese hamster ovary cells that translates natural and synthetic messenger ribonucleic acid templates. Methods Enzymol., 101: 629-635

Nakano, H., T. Tanaka, Y. Kawarasaki and T. Yamane 1994 An increased rate of cell-free protein synthesis by condensing wheat-germ extract with ultrafiltration membranes. Biosci. Biotech. Biochem., 58: $631-634$

Pelham, H. R. and R. J. Jackson 1976 An efficient mRNA-dependent translation system from reticulocyte lysates. Eur. J. Biochem., 67: 247--256

Roberts, S. J., K. N. Chung, K. Nachmanoff and P. C. Elwood 1997 Tissue-specific promoters of the $\alpha$ human folate receptor gene yield transcripts with divergent 5 ' leader sequences and different translational efficiencies. Biochem. J., 326: 439-447

Scheper, G. C., R. G. Vries, M. Broere, M. Usmany, H. O. Voorma, J. M. Vlak and A. A. M. Thomas 1997 Translational properties of the untranslated regions of the p10 messenger RNA of Autographa californica multicapsid nucleopolyhedrovirus. J. Gen. Virol., 78: 687-696

Shin, D. S. and P. Kaesberg 1976 Translation of the RNAs of brome mosaic virus: the monocistronic nature of RNA1 and RNA 2. J. Mol. Biol., 103: 77-88

Shin, D. S., L. C. Lane and P. Kaesberg 1972 Origin of the small component of brome mosaic virus RNA. J. Mol. Biol., 64: 353-362

Vaughn, J. L., R. H. Goodwin, G. J. Tompkins and P. McCawley 1977 The establishment of two cell lines from the insect Spodoptera frugiperda (Lepidoptera; Noctuidae). In Vitro, 13: 213-217

Vlak, J. M., F. A. Klinkenberg, K. J. M. Zaal, M. Usmany, E. C. Klinge-Roode, J. B. Geervliet, J. Roosien and J. W. M. van Lent 1988 Functional studies on the pl0 gene of Autographa californica nuclear polyhedrosis virus using a recombinant expressing a p10- $\beta$-galactosidase fusion gene. J. Gen. Virol., 69: 765-776

Walker, K. A. and J. L. Harwood 1985 Localization of chloroplastic fatty acid synthesis de novo in the stroma. Biochem. J., 226: 551-556

Walter, P. and G. Blobel 1983 Preparation of microsomal membranes for cotranslational protein translocation. Methods Enzymol., 96: 84-93

Yamaguchi, K., S. Hidaka and K. Miura 1982 Relationship between structure of the 5' noncoding region of viral mRNA and efficiency in the initiation step of protein synthesis in a eukaryotic system. Proc Natl. Acad. Sci. USA., 79: 1012-1016 